\title{
Pedagogické př́stupy v multioborové teorii a praxi
}

\author{
KAREL RÝDL
}

\begin{abstract}
$V$ poslední době jsme svědky velkého, až nadměrného důrazu na technické vzdělávání. Uváděné politické a ekonomické argumenty jsou krátkozraké a nebezpečné pro kultivaci osobnosti člověka, který by měl zvládnout možnosti stále novějších technologií v multikulturní společnosti. Je třeba říci, že pedagogické a psychologické př́stupy jsou nanejvýš důležité, potřebné, ba primárně určující.

Proto př́náší časopis Pedagogika ve druhém čísle letošního roku čtyři zásadní studie, které z hledisek různých vědních oborů reagují na aktuální problémy pedagogického charakteru. Osobně si myslím, že jde o velmi důležitý směr, který bude, doufejme, i nadále v odborných časopisech sledován a rozvíjen. Jen tak bude moci pedagogika jako vědní disciplína udržet a prohloubit svoji společenskou prestiž a respekt ostatních, a to nejen společenskovědních a humanitních, ale zejména prírodovědných a technických disciplín, pokud je takové tradiční členění disciplín vzhledem $\mathrm{k}$ mezioborovým nárůstům nadále smysluplné. Naději vzbuzuje zvyšující se počet studií autorů, kterým nejde primárně o „čárku“ a určitý počet RIVových bodů, ale o jejich osobní příspěvky $\mathrm{k}$ řešení složitých problémů v oblastech nejvýznamnějších, ale často jen povrchně popisovaných zdrojů pedagogické teorie a jejího bezprostředního uplatnění ve výchovné a vzdělávací praxi. Zcela záměrně užívám tyto dva krásné české pojmy, nebot termíny vycházející z nepůvodního anglického výrazu „education“ se mi jeví jako ploché, obsahově chudé a zbytečně zaplevelující českou pedagogickou epistemologii. V tomto čísle jde o prýstupy z hlediska historicko-filozofického diskursu, z hlediska osobní psychické vyrovnanosti na základě prožitků, z hlediska role a funkce člověka
\end{abstract}


v pedagogickém procesu postaveném na využití audiovizuálních technologií a z hlediska pedagogického smyslu školskopolitických hodnotících ukazatelů mezinárodních šetření. Nové číslo Pedagogiky je doplněno o recenze nových knižních publikací.

Chtěl bych nyní využít př́ležitosti a nabídnout mezioborovou charakteristiku jednotlivých studií z hlediska subjektivního názorů.

V textu Radima Šípa mne zaujala snaha autora vyjádřit se ke zdánlivě jednoduchému problému, totiž pojetí pedagogického pragmatismu na prŕkladu pedagogických teorií reformních procesů v období existence meziválečné republiky. Jako historika školství mne oslovila hluboká argumentace nového pojetí Deweyova "pragmatismu“ a jeho vlivu na československou pedagogickou reprezentaci, zosobněnou V. Př́hodou, zejména oddělování filozofie od ideologického pojetí pedocentrismu. Významný a jistě hodně diskusní je i Šípův podnět epistemologický s pojmy „pragmatistický“, na př́kladech vztahu cílů a procesů. Věřme, že tento příspěvek rozvine diskusi vedoucí k hlubšímu poznání myšlenkových kořenů československého reformního hnutí.

Druhý př́spěvek je orientován na metaanalýzu pojmu „zážitková pedagogika“ z hlediska mezioborových prŕstupů pedagogických a kinantropologických. Tento pojem se stal jedním z profilových hesel v diskusích o efektivitě kurikulárních a metodických „inovací “ vzdělávací praxe zejména v oblasti povinného vzdělávání. Ivo Jirásek jde dále a uvádí nás do problematiky nejen zneužívání pojmu „zážitková pedagogika“, nedostatečného využívání i v oblasti vzdělávání dospělých a volnočasových aktivitách dospělých, ale nabízí i „správné“ pojetí zážitkové pedagogiky ve smyslu „epistémé“. Osobně si myslím, že tato náročná metoda a forma pedagogické práce je často učiteli podceňována kvůli její pracnosti ve prospěch tradičních forem výuky a často je vnímaná jen jako výukový doplněk za odměnu. $Z$ neuropedagogiky ovšem víme, že osobní zkušenost (tedy i zážitek někoho) je pedagogicky nepřenosný, ale využitelný pouze jako inspirace k vlastnímu zážitku v podobných podmínkách, což má na zapamatování si reakce mozku na určité situace zásadní význam.

Pedeutologicky laděný př́spěvek Jiřrího Mareše poskytuje vedle analytického přehledu dosavadních domácích i zahraničních publikací k tématu role učitele v e-learningu, zajímavou a metodologicky vzorně zpracovanou epistemologii pojmů role - funkce kompetence. Autor se zamýšlí nad proměnami role učitele ve vztahu k žákovi v různých virtuálních prostředích a snaží se klasifikovat jednotlivé role, zejména ty, které jsou ovlivněny technickým využitím virtuálního prostředí. Studie poskytuje mnoho podnětných představ např̀ pro efektivní proměny pregraduální př́ípravy učitelů, dosud silně sledující kurikulární problematiku aprobačních předmětů se stále minimálním zaměřením na porozumění osobnosti dítěte, žáka, studenta a jejich chování a jednání v různých situacích.

Poslední studie autorů Dominika Dvořáka a Jany Strakové, důsledných metodologů pro získávání dat pro porozumění opatřením vzdělávací politiky, nabízí vzornou 
kritickou revizi výsledků vzniklých z šetření PISA 2012. Politici by z nich rádi získali data o zlepšení studijních výsledkủ žáků v matematice zohledněním socioekonomických a demografických parametrů, což se ovšem použitím metodologických př́stupů, které autoři popisují a zdůvodňují, nepotvrdilo. Pravděpodobně jsou problémy s úrovní znalostí v matematice spíše rázu didaktického a metodického, než že by je zlepšovala konkurence mezi blízko ležícími školami stejného druhu. Osobně si myslím, že zlepšení výsledků nelze dosáhnout častějším nebo přísnějším měřením a hodnocením, ale změnou přístupu učitelů $\mathrm{k}$ předmětu a žákům. Možná by stálo za úvahu i finské vnímání výsledků PISA jako jednoho z mnoha způsobů získávání určitých dat pomocí mezinárodních šetření, i když Finové dosahují stabilně přední místa v těchto šetřeních a mohli by to velmi dobře „reklamně“ využít.

Věrím, že čtenáře zaujmou také dvě recenze doplňující druhé číslo Pedagogiky. Jedná se o informace o dvou knihách, které přinášejí důkladnou analýzu aktuálních problémů. První kniha nabízí zamyšlení o roli univerzit v upevňování hodnotové orientace společnosti. Druhá kniha uvádí čtenáře do zcela konkrétních životních představ extrémně alternativní skupiny tzv. freeganů, kteří se snaží prosazovat vlastní životní hodnoty neubližování zvírratům vzdělávacími aktivitami nabízenými většinové společnosti.

Ve všech statích uvedených v tomto čísle časopisu Pedagogika se velmi rozličným způsobem nabízí pedagogika jako obor s vysokým vědomím vlastní individuální i celospolečenské odpovědnosti. 